FOLIA POMERANAE UNIVERSITATIS TECHNOLOGIAE STETINENSIS

Folia Pomer. Univ. Technol. Stetin., Oeconomica 2018, 346(92)3, 69-80

Michał ŚWITKYK ${ }^{1}$, Robert RUSIELIK²

\title{
ZASTOSOWANIE METODY DEA ORAZ INDEKSU PRODUKTYWNOŚCI CAŁKOWITEJ MALMQUISTA DO OCENY EFEKTYWNOŚCI KSZTAŁCENIA NA ZACHODNIOPOMORSKIM UNIWERSYTECIE TECHNOLOGICZNYM W SZCZECINIE W LATACH 2009-2017
}

\section{APPLICATION OF DEA AND MALMQUIST TOTAL FACTOR PRODUCTIVITY INDEX TO EVALUATE THE EFFECTIVENESS OF EDUCATION IN THE WEST POMERANIAN UNIVERSITY OF TECHNOLOGY IN SZCZECIN IN THE YEARS 2009-2017}

\author{
${ }^{1}$ Katedra Zarządzania Przedsiębiorstwami, Zachodniopomorski Uniwersytet Technologiczny \\ w Szczecinie, ul. Klemensa Janickiego 31, 71-270 Szczecin, ORCID: 0000-0002-9494-2802 \\ e-mail: michal.switlyk@zut.edu.pl \\ ${ }^{2}$ Katedra Zarządzania Przedsiębiorstwami, Zachodniopomorski Uniwersytet Technologiczny \\ w Szczecinie, ul. Klemensa Janickiego 31, 71-270 Szczecin, ORCID: 0000-0001-9821-4047 \\ e-mail: robert.rusielik@zut.edu.pl
}

\begin{abstract}
Summary. The aim of the research was to evaluate learning-teaching technical efficiency at 10 faculties of the West Pomeranian University of Technology in Szczecin and its changes in 2009-2017 using the DEA method. The conducted research on efficiency of using financial resources for learning-teaching activity allowed the separation of faculties into three groups: on permanent efficiency, improving their efficiency and constantly ineffective. The faculties that are effective in each of the analyzed years was included: Faculty of Civil Engineering and Architecture, Faculty of Economics, Faculty of Maritime Technology and Transport and the Faculty of Computer Science and Information Technology (except 2009). In the input-oriented model the first position in the technical efficiency ranking was occupied by the Faculty of Civil Engineering and Architecture but in the output-oriented model the first place was belonged to the Faculty of Economics and the Faculty of Maritime Technology and Transport. The average value of the Malmquist Total Factor Productivity Index in 2010-2017 for the input-oriented model was 0.9810, the mean efficiency change index was 0.9998 and the average technological change index was 0.9812. Values of the Malmquist index and its components for the didactic output-oriented model were, respectively: $0.9370,0.9963$ and 0.9405 .
\end{abstract}

Słowa kluczowe: metoda DEA, superefektywność DEA, indeks produktywności całkowitej Malmquista, efektywność kształcenia.

Key words: DEA method, superefficiency DEA, Malmquist Total Productivity Index, study effectiveness.

\section{WSTĘP}

Badanie efektywności publicznych uczelni jest częścią ważnego problemu badawczego, jakim jest efektywność instytucji publicznych. Badania nad problemami efektywności uczelni są prowadzone w różnych częściach świata (np. Coelli 1996; Kao i Hung 2008). W Polsce jako pierwszy problem ten podjął Szuwarzyński (2006a,b), który stosując metody nieparametryczne, badał m.in. efektywność techniczną wydziałów Politechniki Gdańskiej. Następnie w Polsce badania nad efektywnością szkolnictwa wyższego podjęli m.in. Pasewicz 
i Świtłyk (2008), Nazarko i in. (2008), Pasewicz i Świtłyk (2008), Ćwiąkała-Małys (2010), Mongiało i in. (2010), Brzezicki i Wolszczak-Derlacz (2015), Pietrzak (2016), Brzezicki (2017).

Uczelnie publiczne otrzymują z budżetu państwa dotacje na finansowanie zajęć dydaktycznych, pomoc materialną dla studentów, finansowanie lub dofinansowanie inwestycji. Dotacje te stanowią najważniejsze źródło finansowania uczelni i w związku z tym zasadne jest pytanie o efektywność wykorzystania środków publicznych. Zasadne jest również pytanie o efektywność techniczną wewnętrznego podziału dotacji.

Badania prowadzone w Polsce w zasadzie dotyczą dwóch poziomów agregacji. Większość prac dotyczy uczelni - całych zbiorowości (np. uczelni publicznych) lub grup uczelni (np. uczelni rolniczych, uczelni technicznych, uniwersytetów, państwowych wyższych szkół zawodowych). Rzadziej podejmowane są badania, które dotyczą efektywności technicznej wydziałów poszczególnych uczelni - zob. np. Pietrzak (2016), Pietrzak i Baran (2017). Niniejsze badania mieszczą się w tej grupie. Problem mierzenia gospodarności jest problemem złożonym, tak jak samo gospodarowanie. Od metod mierzenia gospodarności wymagamy spełnienia dwóch warunków - ścisłości i małej pracochłonności. Metoda DEA spełnia te warunki.

Celem badań było określenie efektywności kształcenia i jej zmian na Zachodniopomorskim Uniwersytecie Technologicznym w Szczecinie (ZUT) w latach 2009-2016 za pomocą metody DEA oraz próba wyjaśnienia ich efektywności przy zastosowaniu metody superefektywności DEA oraz indeksu produktywności całkowitej Malmquista.

Analizie poddano 10 Wydziałów: Biotechnologii i Hodowli Zwierząt (WBiHZ), Budownictwa i Architektury (WBiA), Ekonomiczny (WEkon.), Elektryczny (WE), Informatyki (WI), Inzynierii Mechanicznej i Mechatroniki (WIMiM), Kształtowania Środowiska i Rolnictwa (WKŚiR), Nauk o Żywieniu i Rybactwa (WNoŻiR), Techniki Morskiej i Transportu (WTMiT), Technologii i Inżynierii Chemicznej (WTilCh).

Dane do analizy zaczerpnięto z opracowanych przez ZUT w Szczecinie materiałów pt. „Informacja o wykonaniu planów (budżetów) przychodów i wydatków (kosztów) jednostek za 12 miesięcy w zakresie działalności dydaktycznej za lata 2009-2017"

Obliczenia wykonano za pomocą programu Frontier Analyst wer. 4.2.0, firmy Banxia Software, oraz pakietu Statistica wer. 13.1.

\section{METODY}

Przez pojęcie efektywności w niniejszej pracy rozumieć należy relację rzeczywistej produktywności obiektu do możliwie najwyższej produktywności. Maksymalną produktywność można wyrazić za pomocą izokwanty; pomiar efektywności jest równoważny z pomiarem odległości od izokwanty. Kwantyfikacja efektywności może odbywać się różnymi sposobami albo za pomocą metod parametrycznych albo przy pomocy metod nieparametrycznych (DEA).

Metoda DEA oparta jest na koncepcji produktywności Debreu (1951) i Farrella (1957). Farrell stworzył koncepcję „granicy efektywności” lub „granicy produkcyjnej” (best practice frontier). Granica ta stanowiła technologiczną granicę możliwości produkcyjnych osiągalnych przez dany podmiot. Koncepcja zakładała pomiar efektywności danej jednostki decyzyjnej w relacji do innych jednostek z podobną technologią produkcji (Rusielik 2017).

Koncepcja ta z pojedynczego nakładu i pojedynczego efektu została rozwinięta do postaci wielowymiarowej dzięki badaniom Charnesa, Coopera i Rhodesa (1978), którzy zaproponowali model zakładający stałe efekty skali, nazywamy najczęściej w literaturze modelem CCR. Wraz 
z rozwojem badań wykorzystujących założenia tej metody tworzono wiele alternatywnych modeli, między innymi wykorzystany w prezentowanych badaniach model BCC zakładający zmienne efekty skali (Banker i in. 1984).

Koncepcja pomiaru efektywności zastosowana w modelach CCR i BCC wykorzystuje jedną z najbardziej popularnych technik opisanych m.in. w pracy „Production frontiers” (Färe i in. 1995). Dysponując s-efektami i m-nakładami, efektywność techniczną można obliczyć z równania:

$$
\frac{\sum_{r=1}^{s} u_{r} y_{r}}{\sum_{i=1}^{m} v_{i} x_{i}}=\frac{u_{1} y_{1}+u_{2} y_{2}+\ldots \ldots+u_{s} y_{s}}{v_{1} x_{1}+v_{2} x_{2}+\ldots \ldots . .+v_{m} x_{m}}
$$

gdzie:

$y_{r}$ - wartość efektu,

$u_{r}$ - waga efektu,

$x_{i}$ - wartość nakładu,

$v_{i}$ - waga nakładu.

Dla każdego obiektu jest rozwiązywane zadanie programowania liniowego, gdzie obliczany współczynnik efektywności ma postać funkcji celu poddanej maksymalizacji, a zmiennymi optymalizowanymi są wagi efektów i wagi nakładów. Dla modeli zorientowanych na nakłady w postaci dualnej przyjmuje ono postać:

$\min _{\Theta, \lambda} \Theta$

przy ograniczeniach (3):

$$
\begin{aligned}
& \mathbf{Y} \boldsymbol{\lambda} \geq \mathbf{Y}_{\mathbf{o}} \\
& \Theta \mathbf{X}_{\mathbf{o}}-\mathbf{X} \boldsymbol{\lambda} \geq 0 \\
& \boldsymbol{\lambda} \geq 0
\end{aligned}
$$

gdzie:

$\mathbf{X}_{\mathbf{0}}$ - wektor nakładów danego obiektu (o wymiarach [1 $\left.\times m\right]$ );

$\mathbf{X}$ - macierz nakładów wszystkich obiektów (o wymiarach $[n \times m]$ );

$\mathbf{Y}_{\mathbf{0}}$ - wektor efektów danego obiektu (o wymiarach [1 $\left.1 \times s\right]$ );

$\mathbf{Y}$ - macierz efektów wszystkich obiektów (o wymiarach $[n \times s]$ );

$\lambda_{1}, \ldots, \lambda_{\sigma}-$ współczynniki kombinacji liniowej;

$\Theta$ - współczynnik efektywności obiektu.

Jak wspomniano, Banker, Charnes i Cooper w 1984 roku zaproponowali rozszerzenie modelu CCR do modelu BCC zakładającego zmienne efekty skali (Banker i in. 1984). W tym celu model CCR można zmodyfikować poprzez dodanie ograniczenia wypukłości $1 ! \lambda=1$, co daje $w$ efekcie model w postaci:

$\min _{\Theta, \lambda} \Theta$

przy ograniczeniach (5):

$$
\begin{aligned}
& \mathbf{Y} \lambda \geq \mathbf{Y}_{\mathbf{o}} \\
& \Theta \mathbf{X}_{\mathbf{o}}-\mathbf{X} \boldsymbol{\lambda} \geq 0 \\
& \mathbf{1} \cdot \boldsymbol{\lambda}=1, \quad \boldsymbol{\lambda} \geq 0
\end{aligned}
$$

Takie założenie powoduje, że $w$ tym modelu wyniki efektywności są bardziej precyzyjne niż wyniki uzyskane przy założeniu CCR, ponieważ uwzględniają efekt skali działania, co oznacza, że obiekty o różnej skali działania są w ograniczonym stopniu porównywane. 
Dodatkowo w celu nadania rang badanym wydziałom posłużono się wersją metody DEA nazywaną modelem superefektywności. W modelu superefektywności DEA zastosowano procedurę rangowania zaproponowaną w pracy Andersena i Petersena (1993). Od strony matematycznej model superefektywności DEA jest identyczny z modelem konwencjonalnym. Wynik obliczeń może być wyższy od 1, przy czym bardzo wysokie wyniki (big, 1000) wskazują, że badany wydział jest wysoce wyspecjalizowany i z tego powodu nie może być porównywany z innymi wydziałami badanej zbiorowości.

Do pomiaru zmian efektywności w czasie wykorzystano indeks produktywności Malmquista. Indeks ten został wprowadzony przez Cavesa, Christiensena i Diewerta w 1982 roku. Wykorzystali oni ideę zaproponowaną przez Malmquista (1953), która zakłada wykorzystanie funkcji odległości do formułowania syntetycznego indeksu zmian wybranego czynnika pomiędzy dwoma punktami w czasie. Prace Cavesa i in. (1982) rozwinęli Färe i in. (1992), formułując model odpowiadający średniej geometrycznej dwóch sąsiadujących (w czasie) indeksów zaproponowanych przez Cavesa, jednocześnie dokonując dekompozycji tego wskaźnika na zmiany efektywności i zmiany technologiczne.

Przyjmując $x$ jako wektor nakładów, $u$ jako wektor efektów i $D$ jako odpowiednie funkcje odległości, model przedstawia równanie (Althin 2001):

$$
{ }^{t} M^{t+1}\left(u^{t}, x^{t}, u^{t+1}, x^{t+1}\right)=\frac{D^{t}\left(u^{t}, x^{t}\right)}{D^{t+1}\left(u^{t+1}, x^{t+1}\right)} \cdot\left[\frac{D^{t+1}\left(u^{t+1}, x^{t+1}\right)}{D^{t}\left(u^{t+1}, x^{t+1}\right)} \cdot \frac{D^{t+1}\left(u^{t}, x^{t}\right)}{D^{t}\left(u^{t}, x^{t}\right)}\right]^{1 / 2}
$$

Obliczone wskaźniki można dekomponować na dwie części, tj. na część związaną ze zmianami efektywności (EC), która obrazuje zmianę położenia (odległości) danego obiektu względem krzywej efektywności, oraz na część związaną ze zmianami technologii (TC), która obrazuje zmianę miejsca położenia krzywej efektywności w odniesieniu do roku poprzedniego. Dekompozycja ta przyjmuje postać:

$$
{ }^{t} M^{t+1}\left(u^{t}, x^{t}, u^{t+1}, x^{t+1}\right)=\underbrace{\frac{D^{t}\left(u^{t}, x^{t}\right)}{D^{t+1}\left(u^{t+1}, x^{t+1}\right)}}_{\begin{array}{c}
\text { Zmiana efektywności } \\
\text { (EC) }
\end{array}} \cdot \underbrace{\left[\frac{D^{t+1}\left(u^{t+1}, x^{t+1}\right)}{D^{t}\left(u^{t+1}, x^{t+1}\right)} \cdot \frac{D^{t+1}\left(u^{t}, x^{t}\right)}{D^{t}\left(u^{t}, x^{t}\right)}\right]^{1 / 2}}_{\begin{array}{c}
\text { Zmiana technologii } \\
\text { (TC) }
\end{array}}
$$

Do obliczeń przyjęto model szkoły wyższej, który obejmował następujące zmienne:

- efekty: liczba studentów i doktorantów (osób);

- nakłady: wydatki osobowe i stypendia; koszty utrzymania tzw. jednostek dzielonych; pozostałe koszty (zakup materiałów, remonty i konserwacja, pozostałe usługi, podróże służbowe i koszty przejazdów, szkolenia i konferencje, pozostałe koszty, usługi wewnętrzne i inne); amortyzacja środków trwałych oraz wartości niematerialne i prawne finansowane ze środków na działalność dydaktyczną i przeznaczone na zakupy środków trwałych, a także wartości niematerialne i prawne o wartości jednostkowej powyżej 3500 zł.

Dane do analizy zaczerpnięto z opracowanych przez ZUT w Szczecinie materiałów pt. „Informacja o wykonaniu planu (budżetów) przychodów i wydatków (kosztów) jednostek za 12 miesięcy w zakresie działalności dydaktycznej za lata 2009-2017". Podstawowe statystyki zamieszczono w tab. 1. 
Tabela 1. Statystyka opisowa zmiennych przyjętych do modelu w latach 2009-2017

\begin{tabular}{|c|c|c|c|c|c|c|c|}
\hline Wyszczególnienie & Średnia & Mediana & Minimum & Maksimum & $\begin{array}{c}\text { Odchylenie } \\
\text { standardowe }\end{array}$ & $\begin{array}{c}\text { Współczynnik } \\
\text { zmienności }\end{array}$ & Skośność \\
\hline Wydatki osobowe i stypendia [zł] & 11524904 & 10899216 & 4717187 & 19858928 & 3737257 & 32,4 & 0,19 \\
\hline Koszty stałe [zł] & 743001 & 757360 & 274767 & 1248102 & 285431 & 38,4 & 0,11 \\
\hline Koszty utrzymania [zł] „,jednostek dzielonych” & 127499 & 60495 & 11212 & 641942 & 154971 & 121,5 & 1,80 \\
\hline $\begin{array}{l}\text { Pozostałe koszty (zakup materiałów, remonty i konserwacja, po- } \\
\text { zostałe usługi, podróże służbowe i koszty przejazdów, szkolenia } \\
\text { i konferencje, pozostałe koszty, usługi wewnętrzne i inne) [zł] }\end{array}$ & 466997 & 397078 & 122045 & 2143482 & 301025 & 64,5 & 2,33 \\
\hline $\begin{array}{l}\text { Amortyzacja środków trwałych oraz wartości niematerialne } \\
\text { i prawne finansowane ze środków na działalność dydaktyczną } \\
\text { i na zakupy środków trwałych oraz wartości niematerialne i praw- } \\
\text { ne o wartości powyżej } 3500 \text { zł }\end{array}$ & 210897 & 148735 & 3526 & 1753730 & 259347 & 123,0 & 3,67 \\
\hline Studenci i doktoranci & 1222 & 1050 & 340 & 3523 & 714 & 58,4 & 1,60 \\
\hline Studenci & 1180 & 996 & 334 & 3513 & 722 & 61,2 & 1,61 \\
\hline Doktoranci & 42 & 42 & 0 & 111 & 29 & 69,1 & 0,58 \\
\hline
\end{tabular}




\section{WYNIKI}

Rozwiązanie obliczanych modeli dostarczyło kilka rodzajów wyników, jednak ze względu na ograniczenia objętości tekstu zostaną przedstawione podstawowe wyniki charakteryzujące efektywność techniczną badanej zbiorowości oraz wskaźniki obliczone za pomocą indeksu produktywności całkowitej Malmquista ().

W tabeli 2 przedstawiono wskaźniki efektywności technicznej BCC dla badanej zbiorowości. W 2009 r. przeciętny wskaźnik efektywności technicznej BCC w modelu ukierunkowanym na nakłady wyniósł 87,9\%; spośród 10 wydziałów 5 było efektywnych (WBiA, WBiHZ, WEkon., WNoŻiR, WTMiT). Pozostałe wydziały były nieefektywne, przy czym uwagę zwraca wysoki poziom nieefektywności dwóch wydziałów - WKŚiR (55,7\%) i WTilCh (51,8\%). Średni wskaźnik efektywności technicznej w 2009 r. oznacza, że analizowane nakłady można zmniejszyć o 12,1\%. W 2010 r. przeciętny wskaźnik efektywności technicznej dla uczelni ukształtował się na poziomie 83,7\%; 5 wydziałów było efektywnych (WBiA, WBiHZ, WEkon., WI, WTMiT). Pozostałe wydziały były nieefektywne technicznie. Ich współczynniki efektywności technicznej wahały się od 47,9\% (WTilCh) do 84,0\%\% (WE).

Tabela 2. Wskaźniki efektywności technicznej BCC dla modeli ukierunkowanych na nakłady i na efekty [\%]

\begin{tabular}{|c|c|c|c|c|c|c|c|c|c|}
\hline Wydział & 2009 & 2010 & 2011 & 2012 & 2013 & 2014 & 2015 & 2016 & 2017 \\
\hline \multicolumn{10}{|c|}{ Model ukierunkowany na nakłady } \\
\hline WBiHZ & 100,0 & 100,0 & 100,0 & 100,0 & 68,8 & 98,3 & 85,4 & 100,0 & 94,9 \\
\hline WBiA & 100,0 & 100,0 & 100,0 & 100,0 & 100,0 & 100,0 & 100,0 & 100,0 & 100,0 \\
\hline WEkon. & 100,0 & 100,0 & 100,0 & 100,0 & 100,0 & 100,0 & 100,0 & 100,0 & 100,0 \\
\hline WE & 89,1 & 84,0 & 82,6 & 80,1 & 91,0 & 78,5 & 77,0 & 75,5 & 87,5 \\
\hline WI & 95,7 & 100,0 & 100,0 & 100,0 & 100,0 & 100,0 & 100,0 & 100,0 & 100,0 \\
\hline WIMiM & 86,2 & 70,4 & 64,1 & 79,9 & 69,5 & 69,7 & 62,9 & 64,8 & 77,7 \\
\hline WKŚiR & 55,7 & 60,0 & 53,5 & 51,6 & 51,5 & 51,0 & 49,0 & 63,6 & 83,1 \\
\hline WNoŻiR & 100,0 & 75,0 & 68,6 & 68,0 & 63,7 & 61,9 & 69,1 & 68,8 & 100,0 \\
\hline WTMiT & 100,0 & 100,0 & 100,0 & 100,0 & 100,0 & 100,0 & 100,0 & 100,0 & 100,0 \\
\hline WTilCh & 51,8 & 47,9 & 42,3 & 45,9 & 40,6 & 40,9 & 42,8 & 40,3 & 38,9 \\
\hline ZUT & 87,9 & 83,7 & 81,1 & 82,5 & 78,5 & 80,0 & 78,6 & 81,3 & 88,2 \\
\hline \multicolumn{10}{|c|}{ Model ukierunkowany na efekty } \\
\hline WBiHZ & 100,0 & 100,0 & 100,0 & 100,0 & 70,4 & 87,0 & 58,7 & 100,0 & 69,9 \\
\hline WBiA & 100,0 & 100,0 & 100,0 & 100,0 & 100,0 & 100,0 & 100,0 & 100,0 & 100,0 \\
\hline WEkon. & 100,0 & 100,0 & 100,0 & 100,0 & 100,0 & 100,0 & 100,0 & 100,0 & 100,0 \\
\hline WE & 73,5 & 70,3 & 66,7 & 70,1 & 84,0 & 71,6 & 67,4 & 67,2 & 82,8 \\
\hline WI & 93,5 & 100,0 & 100,0 & 100,0 & 100,0 & 100,0 & 100,0 & 100,0 & 100,0 \\
\hline WIMiM & 80,4 & 59,3 & 53,8 & 84,1 & 65,2 & 68,1 & 61,4 & 71,7 & 82,1 \\
\hline WKŚiR & 67,4 & 41,6 & 39,5 & 43,6 & 43,7 & 58,4 & 55,2 & 48,4 & 76,7 \\
\hline WNoŻiR & 100,0 & 51,5 & 52,7 & 57,1 & 53,6 & 55,5 & 54,5 & 48,2 & 100,0 \\
\hline WTMiT & 100,0 & 100,0 & 100,0 & 100,0 & 100,0 & 100,0 & 100,0 & 100,0 & 100,0 \\
\hline WTilCh & 37,4 & 28,6 & 24,7 & 36,5 & 29,8 & 29,8 & 31,0 & 30,4 & 28,5 \\
\hline ZUT & 85,2 & 75,1 & 73,7 & 79,1 & 74,7 & 77,0 & 72,8 & 76,6 & 84,0 \\
\hline
\end{tabular}


Podobnie jak w roku poprzednim najniższymi wskaźnikami efektywności technicznej charakteryzowały się dwa wydziały - WTilCh (47,9\%) i WKŚiR (60,0\%). W latach 2011-2012 przeciętny wskaźnik efektywności technicznej dla ZUT wyniósł odpowiednio 81,1\% i 82,5\%. Efektywne w latach 2011-2012 były: WBiA, WBiHZ, WEkon., WI, WTMiT. Najniższe wskaźniki efektywności technicznej odnotowały w 2011 r. WTilCh (42,3\%), WKŚiR (53,5\%) i WIMiM (64,1\%). W 2012 r najniższe wskaźniki efektywności charakteryzowały WTilCh (45,9\%) i WKŚiR (51,6\%). W latach 2013-2015 przeciętny wskaźnik efektywności technicznej wyniósł odpowiednio $78,5 \%, 80,0 \%$ i 78,6\%. W tych latach 4 wydziały były efektywne (WBiA, WEkon., WI, WTMiT). Wydziałami o najniższych współ-czynnikach efektywności technicznej w latach 2013-2015 były WTilCh i WKŚiR.

W 2016 r. średni wskaźnik efektywności technicznej dla ZUT wyniósł 81,3\%; wśród 10 wydziałów 5 było efektywnych (WBiHZ, WBiA, WEkon., WI, WTMiT). Najniższymi wskaźnikami efektywności technicznej w 2016 r. charakteryzowały się 2 wydziały - WTilCh $(40,3 \%)$ i WKŚiR (63,6\%). W 2017 r. przeciętny wskaźnik efektywności technicznej wynosił 88,2\%; 5 wydziałów było efektywnych (WBiA, WEkon., WI, WNoŻiR, WTMiT). Najniższym wskaźnikiem efektywności technicznej w 2017 r. charakteryzował się WTilCh (38,9\%).

Model uczelni zorientowany na efekty (output) odpowiada na pytanie, o ile mogą wzrosnąć efekty bez zmiany poziomu nakładów, przy założeniu zmiennych (BCC) efektów skali. Analizując wyniki obliczeń wskaźnika dla tego modelu, zauważyć można, że wskaźniki efektywności obliczone dla tego modelu są nieco niższe od wskaźników modelu ukierunkowanego na minimalizację nakładów; podobnie, jak w modelu zorientowanym na nakłady (input), wydziałami o najniższych wskaźnikach efektywności były: WTilCh, WKŚiR i WNoŻi R.

W tabeli 3 zamieszczono wyniki obliczeń superefektywności DEA. Zaznaczyć należy, że metoda ta pozwala na ustalenie rankingu obiektów efektywnych. $W$ rankingu efektywności w modelu zorientowanym na input miejsce pierwsze zajmuje WBiA, kolejne miejsca zajmują WTMiT, WEkon., WI. W modelu zorientowanym na output miejsce pierwsze zajmują WEkon., WTMiT, następne - WBiA, WI; oba rankingi zamykają WKŚiR i WTilCh.

Wskaźniki efektywności technicznej obliczone dla lat 2009-2017 zostały wykorzystane do obliczenia indeksów produktywności Malmquista (TFP) i określenia zmian efektywności w czasie. Indeks równy 1 wskazuje na brak zmian, natomiast mniejszy lub większy wskazuje na te zmiany. Następnie została dokonana dekompozycja indeksów na część związaną ze zmianami efektywności (EC) i na część związaną ze zmianami technologii (TC). Wyniki pomiaru obejmujące pełny okres badawczy zamieszczono w tab. 4.

Indeks całkowitej produktywności Malmquista w latach 2010-2017 obliczony dla modelu zorientowanego na nakłady, wynosił 0,9810, a jego wartość wahała się od 0,8892 do 1,1059. Oznacza to, że produktywność uczelni obniża się w tym modelu o 1,9\% rocznie. W badanym okresie tylko w trzech latach $(2011,2012,2015)$ uczelnia charakteryzowała się indeksem produktywności Malmquista większym od 1. Największy indeks całkowitej produktywności Malmquista uczelnia odnotowała w 2011 r.; wyniósł on 10,6\%.

Przeciętne zmiany efektywności (EC) w analizowanym modelu były zbliżone do $1(0,9998)$; można przyjąć, że w analizowanym okresie były one neutralne. Poziom indeksów efektywności (EC) większy od 1 odnotowano w 4 latach (2012, 2014, 2016, 2017); wahał się on od $1,81 \%$ do $9,23 \%$. Przeciętny indeks zmian technologii (TC) wynosił 0,9812; był on większy od 1 w pięciu latach $(2010,2011,2012,2013,2015)$ i mieścił się w graniach od 0,28\% do 15,3\%. 
Tabela 3. Wyniki obliczeń superefektywności DEA - ranking wydziałów ze względu na poziom efektywności technicznej

\begin{tabular}{|c|c|c|c|c|c|c|c|c|c|c|c|c|c|c|c|c|c|c|}
\hline \multirow[b]{2}{*}{ Wydział } & \multicolumn{2}{|c|}{2009} & \multicolumn{2}{|c|}{2010} & \multicolumn{2}{|c|}{2011} & \multicolumn{2}{|c|}{2012} & \multicolumn{2}{|c|}{2013} & \multicolumn{2}{|c|}{2014} & \multicolumn{2}{|c|}{2015} & \multicolumn{2}{|c|}{2016} & \multicolumn{2}{|c|}{2017} \\
\hline & wynik & miejsce & wynik & miejsce & wynik & miejsce & wynik & miejsce & wynik & miejsce & wynik & miejsce & wynik & miejsce & wynik & miejsce & wynik & miejsce \\
\hline \multicolumn{19}{|c|}{ input } \\
\hline WBiHZ & 241,2 & 2 & 135,6 & 4 & 121,4 & 4 & 125,5 & 5 & 68,8 & 7 & 98,3 & 5 & 85,4 & 4 & 158,8 & 4 & 94,8 & 6 \\
\hline WBiA & 1000,0 & 1 & 1000,0 & 1 & 1000,0 & 1 & 1000,0 & 1 & 1000,0 & 1 & 1000,0 & 1 & 1000,0 & 1 & 1000,0 & 1 & 1000,0 & 1 \\
\hline WEkon. & 177,3 & 3 & 135,1 & 5 & 168,6 & 3 & 148,8 & 4 & 157,9 & 4 & 142,5 & 4 & 159,8 & 2 & 147,2 & 5 & 145,7 & 4 \\
\hline WE & 89,1 & 7 & 83,95 & 6 & 82,6 & 6 & 80,0 & 6 & 91,0 & 5 & 78,5 & 6 & 77,0 & 5 & 75,5 & 6 & 87,4 & 7 \\
\hline WI & 95,7 & 6 & 318,93 & 2 & 113,9 & 5 & 158,6 & 3 & 178,7 & 3 & 212,4 & 3 & 140,9 & 3 & 351,6 & 3 & 159,2 & 3 \\
\hline WIMiM & 86,2 & 8 & 70,37 & 8 & 64,1 & 8 & 79,9 & 7 & 69,5 & 6 & 69,7 & 7 & 62,9 & 7 & 64,8 & 8 & 77,7 & 9 \\
\hline WKŚiR & 55,7 & 9 & 60 & 9 & 53,5 & 9 & 51,6 & 9 & 51,59 & 9 & 51,0 & 9 & 49,0 & 8 & 63,6 & 9 & 83,1 & 8 \\
\hline WNoŻiR & 107,6 & 5 & 75,02 & 7 & 68,6 & 7 & 67,9 & 8 & 63,7 & 8 & 61,9 & 8 & 69,1 & 6 & 68,8 & 7 & 107,7 & 5 \\
\hline WTilCh & 51,8 & 10 & 47,86 & 10 & 42,3 & 10 & 45,7 & 10 & 40,6 & 10 & 40,9 & 10 & 42,8 & 9 & 40,3 & 10 & 38,9 & 10 \\
\hline WTMiT & 142,3 & 4 & 226,55 & 3 & 235,1 & 2 & 226,3 & 2 & 317,9 & 2 & 570,6 & 2 & 1000,0 & 1 & 489,1 & 2 & 263,5 & 2 \\
\hline \multicolumn{19}{|c|}{ output } \\
\hline WBiHZ & 1000,0 & 1 & 1000,0 & 1 & 1000,0 & 1 & 1000,0 & 1 & 70,4 & 5 & 87,0 & 4 & 58,7 & 6 & 1000,0 & 1 & 69,9 & 7 \\
\hline WBiA & 184,9 & 2 & 364,5 & 2 & 460,9 & 2 & 364,2 & 2 & 284,7 & 2 & 270,5 & 2 & 234,8 & 2 & 142,9 & 2 & 135,6 & 3 \\
\hline WEkon. & 1000,0 & 1 & 1000,0 & 1 & 1000,0 & 1 & 1000,0 & 1 & 1000,0 & 1 & 1000,0 & 1 & 1000,0 & 1 & 1000,0 & 1 & 1000,0 & 1 \\
\hline WE & 73,5 & 6 & 70,3 & 3 & 66,7 & 4 & 70,1 & 5 & 84,0 & 4 & 71,6 & 5 & 67,4 & 4 & 67,2 & 4 & 82,8 & 4 \\
\hline WI & 93,5 & 4 & 1000,0 & 1 & 153,2 & 3 & 179,2 & 3 & 217,2 & 3 & 234,5 & 3 & 134,9 & 3 & 1000,0 & 1 & 144,5 & 2 \\
\hline WIMiM & 80,4 & 5 & 59,3 & 4 & 53,8 & 5 & 84,1 & 4 & 65,2 & 6 & 68,1 & 6 & 61,4 & 5 & 71,7 & 3 & 82,1 & 5 \\
\hline WKŚiR & 67,4 & 7 & 41,6 & 6 & 39,5 & 7 & 43,6 & 7 & 43,7 & 8 & 58,4 & 7 & 55,2 & 7 & 48,4 & 5 & 76,7 & 6 \\
\hline WNoŻiR & 105,5 & 3 & 51,5 & 5 & 52,7 & 6 & 57,1 & 6 & 53,6 & 7 & 55,5 & 8 & 54,5 & 8 & 48,2 & 6 & 1000,0 & 1 \\
\hline WTilCh & 37,4 & 8 & 28,6 & 7 & 24,7 & 8 & 36,5 & 8 & 29,8 & 9 & 29,8 & 9 & 31,0 & 9 & 30,4 & 7 & 28,5 & 8 \\
\hline WTMiT & 1000,0 & 1 & 1000,0 & 1 & 1000,0 & 1 & 1000,0 & 1 & 1000,0 & 1 & 1000,0 & 1 & 1000,0 & 1 & 1000,0 & 1 & 1000,0 & 1 \\
\hline
\end{tabular}


Tabela 4. Średnie indeksy produktywności całkowitej Malmquista i jego elementy składowe

\begin{tabular}{|c|c|c|c|}
\hline Wyszczególnienie & TFP & EC & TC \\
\hline \multicolumn{4}{|c|}{ input } \\
\hline 2010 & 0,9945 & 0,9502 & 1,0466 \\
\hline 2011 & 1,1059 & 0,9572 & 1,1553 \\
\hline 2012 & 1,0254 & 1,0226 & 1,0028 \\
\hline 2013 & 0,9960 & 0,9444 & 1,0545 \\
\hline 2014 & 0,8821 & 1,0181 & 0,8663 \\
\hline 2015 & 1,0272 & 0,9855 & 1,0423 \\
\hline 2016 & 0,8892 & 1,0368 & 0,8576 \\
\hline 2017 & 0,9475 & 1,0923 & 0,8674 \\
\hline Średnia & 0,9810 & 0,9998 & 0,9812 \\
\hline \multicolumn{4}{|c|}{ output } \\
\hline 2010 & 0,9750 & 0,8441 & 1,1551 \\
\hline 2011 & 1,0082 & 0,9682 & 1,0413 \\
\hline 2012 & 0,9676 & 1,1121 & 0,8701 \\
\hline 2013 & 0,9053 & 0,9333 & 0,9700 \\
\hline 2014 & 0,8330 & 1,0434 & 0,7983 \\
\hline 2015 & 0,9429 & 0,9421 & 1,0008 \\
\hline 2016 & 0,8924 & 1,0423 & 0,8562 \\
\hline 2017 & 0,9846 & 1,1173 & 0,8812 \\
\hline Średnia & 0,9370 & 0,9963 & 0,9405 \\
\hline
\end{tabular}

Indeks Malmquista, obliczony dla modelu ukierunkowanego na efekty, wynosił średnio 0,9370 i tylko w 2011 roku był większy od 1 . Oznacza to, że w tym podejściu produktywność zmniejsza się rocznie średnio o 6,3\%. Przeciętne zmiany efektywności (EC) obliczone dla tego modelu wynosiły 0,9963 ; w czterech latach $(2012,2014,2016,2017)$ były one większe od 1. Średnie zmiany indeksu zmian technologii (TC) wynosiły 0,9405 ; indeks ten był w trzech latach $(2010,2011,2015)$ większy od 1.

W tab. 5 zamieszczono przeciętne wartości indeksu całkowitej produktywności Malmquista (TFP) obliczonego dla poszczególnych wydziałów w latach objętych badaniami.

Z wyników zamieszczonych w tabeli wynika, że w modelu ukierunkowanym na nakłady na przeciętny spadek indeksu produktywności całkowitej Malmquista, w latach 2010-2017, w wysokości $1,9 \%$ rocznie miały wpływ różne wydziały. W analizowanych latach największe przeciętne przyrosty indeksu całkowitej produktywności Malmquista (MPI) odnotowano na WBiA $(8,08 \%)$ i WTMiT (3,86\%). Pozostałe wydziały miały wskaźnik TFP niższy od 1, co wpływało na obniżenie wskaźnika TFP obliczonego dla uczelni. Zwraca uwagę to, że tylko 2 wydziały miały indeks zmian efektywności (EC) większy od 1 (WI, WKŚiR). W omawianym podejściu indeks zmian technologicznych (TC) był wyższy od 1 na trzech wydziałach (WBiA, WTilCh, WTMiT).

W modelu uczelni ukierunkowanym na efekty żaden z wydziałów nie uzyskał indeksu Malmquista większego od 1. Podobnie kształtował się indeks zmian technologicznych. Indeks zmian efektywności był większy od 1 na Wydziałach: Elektrycznym, Informatyki, Inżynierii Mechanicznej i Mechatroniki, Kształtowania Środowiska i Rolnictwa. 
Tabela 5. Średnie zmiany indeksu produktywności całkowitej Malmquista wydziałów ZUT

\begin{tabular}{|l|c|c|c|}
\hline \multicolumn{1}{|c|}{ Wyszczególnienie } & TFP & EC & TC \\
\hline WBiHZ & 0,9334 & 0,9934 & 0,9396 \\
\hline WBiA & 1,0808 & 1,0000 & 1,0808 \\
\hline WEkon. & 0,9830 & 1,0000 & 0,9830 \\
\hline WE & 0,9476 & 0,9977 & 0,9498 \\
\hline WI & 0,9545 & 1,0055 & 0,9492 \\
\hline WIMiM & 0,9457 & 0,9871 & 0,9580 \\
\hline WKŚiR & 0,9814 & 1,0514 & 0,9334 \\
\hline WNoŻiR & 0,9786 & 1,0000 & 0,9785 \\
\hline WTilCh & 0,9754 & 0,9647 & 1,0110 \\
\hline WTMiT & 1,0386 & 1,0000 & 1,0386 \\
\hline ZUT & 0,9810 & 0,9998 & 0,9812 \\
\hline & Model zorientowany na efekty & \\
\hline WBiHZ & 0,8914 & 0,9562 & 0,9322 \\
\hline WBiA & 0,8769 & 1,0000 & 0,8769 \\
\hline WEkon. & 0,9850 & 1,0000 & 0,9850 \\
\hline WE & 0,9486 & 1,0150 & 0,9346 \\
\hline WI & 0,9620 & 1,0085 & 0,9539 \\
\hline WIMiM & 0,9496 & 1,0026 & 0,9472 \\
\hline WKŚiR & 0,9022 & 1,0163 & 0,8877 \\
\hline WNoŻiR & 0,9644 & 1,0000 & 0,9644 \\
\hline WTilCh & 0,8989 & 0,9666 & 0,9300 \\
\hline WTMiT & 1,0000 & 1,0000 & 1,0000 \\
\hline ZUT & 0,9370 & 0,9963 & 0,9405 \\
\hline
\end{tabular}

\section{WNIOSKI}

1. Przeprowadzone badania nad efektywnością wykorzystania środków finansowych, przeznaczonych przez Zachodniopomorski Uniwersytet Technologiczny na prowadzenie zajęć dydaktycznych, pozwoliły na wyodrębnienie trzech grup wydziałów: o stałej efektywności, wydziałów poprawiających swą efektywność oraz wydziałów stale nieefektywnych. Do wydziałów efektywnych w każdym z badanych lat należą: Wydział Budownictwa i Architektury, Wydział Ekonomiczny, Wydział Techniki Morskiej i Transportu oraz Wydział Informatyki (z wyjątkiem 2009 r.). Do grupy wydziałów poprawiających swą efektywność należą: Wydział Biotechnologii i Hodowli Zwierząt, Wydział Elektryczny, Wydział Kształtowania Środowiska i Rolnictwa, Wydział Nauk o Żywności i Rybactwa. Do wydziałów o względnie stałej nieefektywności zaliczyć należy: Wydział Technologii i Inżynierii Chemicznej i Wydział Inżynierii Mechanicznej i Mechatroniki.

2. Pierwsze miejsce $w$ rankingu efektywności technicznej w modelu ukierunkowanym na nakłady zajmuje Wydział Budownictwa i Architektury, natomiast w modelu ukierunkowanym na efekty pierwsze miejsce zajmują Wydział Ekonomiczny i Wydział Techniki Morskiej i Transportu. 
3. Przeciętna wartość indeksu produktywności całkowitej Malmquista w latach 2010-2017 dla modelu ukierunkowanego na nakłady wynosiła 0,9810, średni indeks zmian efektywności wynosił 0,9998, a średni indeks zmian technologiczny - 0,9812. Dla modelu dydaktycznego uczelni zorientowanego na efekty wartości indeksu Malmquista i jego części składowych wynosiły odpowiednio: 0,9370, 0,9963 i 0,9405.

\section{PIŚMIENNICTWO}

Althin R. 2001. Measurement of productivity changes: Two Malmquist Index Approaches. J. Product. Anal. 16, 107-128.

Andersen P., Petersen N.C. 1993. A procedure for ranking efficient units in data envelopment analysis. Manag. Sci. 39, 1261-1264.

Banker R.D., A. Charnes, Cooper W.W. 1984. Some models for estimating technical and scale inefficiency in Data Envelopment Analysis. Manag. Sci. 30,1078-1092.

Brzezicki Ł. 2017. Efektywność działalności dydaktycznej polskiego szkolnictwa wyższego. Wiad. Statyst. 11(678), 56-73.

Brzezicki Ł., Wolszczak-Derlacz J. 2015. Pomiar efektywności kształcenia i produktywności publicznych szkół wyższych za pomocą nieparametrycznej metody DEA i indeksu Malmquista. Gosp. Rynek Edukacja 16(4), 13-20.

Caves D., Christensen L., Diewert E. 1982. The economic theory of index numbers and the measurement of input, output, and productivity. Econometrica 50(6), 1393-1414.

Charnes A., Cooper W.W., Rhodes E. 1978. Measuring the efficiency of decision making units. Europ. J. Operat. Res. 2(6), 429-444.

Coelli T. 1996. Assessing the performance of Australian universities using Data Envelopment Analysis. Centre for Efficiency and Productivity Analysis, University of New England, NSW.

Ćwiąkała-Małys A. 2010. Pomiar efektywności procesu kształcenia w publicznym szkolnictwie akademickim. Wrocław, Wydaw. UWroc.

Debreu G. 1951. The coefficient of recourse utilisation. Econometrica 19(3), 273-292.

Farrell M.J. 1957. The measurement of productive efficiency. J. Royal Statist. Soc., Ser. A 120(3), 253-281.

Färe R., Grosskopf S., Lindgren B., Roos P. 1992. Productivity changes in Swedish pharmacies 1980-1989: A nonparametric Malmquist approach. J. Product. Anal. 3, 85-101.

Färe R., Grosskopf S., Lovell C.A.K. 1995. Production frontiers. Cambridge, Cambridge University Press.

Kao C., Hung H.-T. 2008. Efficiency analysis of university departments: An empirical study. Omega 36(2008). The Internat. J. Manag. Sci., 653-664.

Mongiało Z., Pasewicz W., Świtłyk M. 2010. Z badań nad efektywnością szkolnictwa wyższego efektywność kształcenia w publicznych uczelniach technicznych w latach 2001-2005. Folia Pomer. Univ. Technol. Stetin., Oeconomica 282(60), 87-102.

Nazarko J., Komuda M., Kuźmicz K., Szubzda E., Urban J. 2008. Metoda DEA w badaniu efektywności instytucji sektora publicznego na przykładzie szkół wyższych. Bad. Oper. Decyzje 4, 89-105.

Pasewicz W., Świtłyk M. 2008. Zastosowanie metody DEA oraz indeksu produktywności całkowitej Malmquista do oceny efektywności kształcenia w państwowych szkołach wyższych. Folia Univ. Agric. Stetin., Ser. Oeconomica 267(53), 161-176.

Pietrzak P. 2016. Efektywność sektora publicznego na przykładzie szkolnictwa wyższego w Polsce. Rozprawa doktorska. Warszawa, SGGW (niepublikowana).

Pietrzak P., Baran J. 2017. Application of the Malmquist Productivity Index to examine changes in the efficiency of humanities faculties. Acta Sci. Pol., Oeconomia 16(3), 43-52. 
Rusielik R. 2017. Skala a efektywność techniczna produkcji trzody chlewnej, w: Wyzwania na rynku żywca wieprzowego w Polsce. Warszawa, SGGW, 69-78.

Szuwarzyński A. 2006a. Rola pomiaru efektywności szkoły wyższej w kształtowaniu jej pozycji konkurencyjnej, w: Konkurencja na rynku usług edukacji wyższej. Red. J. Dietl, Z. Sapijaszko. Łódź, Fundacja Edukacyjna Przedsiębiorczości, 213-224.

Szuwarzyński A. 2006b. Metoda DEA pomiaru efektywności działalności szkół wyższych. Nauka Szkol. Wyż. 2(28), 78-88.

Streszczenie. Celem badań było określenie efektywności technicznej kształcenia prowadzonego na 10 wydziałach Zachodniopomorskiego Uniwersytetu Technologicznego w Szczecinie i jej zmian w latach 2009-2017; użyto metody DEA. Badania nad efektywnością wykorzystania środków finansowych, przeznaczonych przez Zachodniopomorski Uniwersytet Technologiczny na prowadzenie zajęć dydaktycznych, pozwoliły na wyodrębnienie trzech grup wydziałów: o stałej efektywności, wydziałów poprawiających swą efektywność oraz wydziałów stale nieefektywnych. Do wydziałów efektywnych $w$ każdym $z$ badanych lat należą: Wydział Budownictwa i Architektury, Wydział Ekonomiczny, Wydział Techniki Morskiej i Transportu oraz Wydział Informatyki (z wyjątkiem 2009 r.). Pierwsze miejsce w rankingu efektywności technicznej w modelu ukierunkowanym na input zajmuje Wydział Budownictwa i Architektury, natomiast w modelu ukierunkowanym na output pierwsze miejsce zajmują Wydział Ekonomiczny i Wydział Techniki Morskiej i Transportu. Przeciętna wartość indeksu produktywności całkowitej Malmquista w latach 2010-2017 dla modelu ukierunkowanego na input wynosiła 0,9810, średni indeks zmian efektywności wynosił 0,9998, a średni indeks zmian technologicznych - 0,9812. Dla modelu dydaktycznego uczelni zorientowanego na output wartości indeksu Malmquista i jego części składowych wynosiły odpowiednio: 0,9370, 0,9963 i 0,9405. 